\title{
THE MAGISTRACY AND JUDICIAL INDEPENDENCE: A STATE OF MIND OR THE STATE OF CIRCUMSTANCES?
}

\author{
by Dawn Neethling*
}

\author{
Conscience is the chamber of justice \\ Origen \\ I expect nothing, I fear nothing, I am free \\ Nikos Kazantzakis
}

Is judicial independence merely a state of mind or is institutional independence essential for judicial independence? This question is especially relevant with regard to the South African magistracy.

Before 1994 the magistracy functioned in a system where no institutional independence existed. It was only with the advent of the interim Constitution in 1994 that institutional independence and the protection thereof began to apply to the magistracy. The question arises whether the Constitution freed the minds of the magistracy as if by magic, and whether institutional independence necessarily brings with it an independent state of mind.

The following aspects are dealt with in this discussion:

- the lack of institutional independence of magistrates before at least 1993, and the views of magistrates on their judicial independence at that stage;

- the reality that magistrates did perform a substantial amount of judicial work at that stage;

- the changes brought about by the Magistrates Act in $1993^{1}$ and the interim Constitution in $1994 ;^{2}$

- different opinions on and definitions of judicial independence;

- the current attitude of the executive towards the independence of the judiciary.

There seems to be a general perception that before 1994 the magistracy did not enjoy judicial independence at all. ${ }^{3}$ This perception is based on the fact that magistrates were public servants up to 1993 and not institutionally independent before 1994. Even

BJuris LLB (PU for CHE), Additional Magistrate, Pretoria Magistrate's Court.

Act 90 of 1993.

Act 200 of 1993.

See R Laue 'Judicial independence and accountability' (1998) 1 The Judicial Officer 89-99. 
amongst magistrates themselves, opinions differ on whether they were judicially independent before 1994. Some magistrates interviewed during research done for the Centre for the Study of Violence and Reconciliation ${ }^{4}$ maintained that they had always regarded themselves as judicially independent in the pre-1994 period. They regarded judicial independence largely as freedom from political interference in their judicial work. The generally accepted opinion, also expressed by some magistrates interviewed for the abovementioned research, however, seems to be that magistrates were manifestly not independent and were accountable to the state. These opinions are based on the fact that before 1994 (or at least before 1993) magistrates were not institutionally independent. Learned writers and researchers generally accept that magistrates who maintain that they were judicially independent are either not telling the truth or are deluding themselves. They seem to be more inclined to accept the opinion of those individual magistrates who were prepared to paint a grim picture regarding the absence of judicial independence of the pre-1994 magistracy. This group of magistrates acknowledged that the fact that they were public servants was unacceptable. They also acknowledged that the subjective fears of not being promoted or being transferred by the executive if the state was dissatisfied with a judgment, might have impacted on their independence. 5

What was evident from the research was that magistrates expressed a sense of an individual capacity to be independent while occupying a compromised structural position. The researchers also reported that, at the time of delivering their report, independence and accountability were issues of considerable and ongoing significance for the magistracy. This has of course become even more acute in the period subsequent to the publication of the report. The researchers reported that magistrates perceived the implications of judicial independence to be the absence of interference, the freedom to criticise the state and the ability to administer justice to all.

Mr Laue, a senior magistrate at the Magistrates Court in Durban, clearly supports the idea that institutional independence is a sine qua non for judicial independence. He states: '[b]efore 1994 the impact of parliamentary sovereignty on ... magistrates, who were public servants, was that those magistrates who presided in the lower courts were beholden to no one but the laws and their makers. Judicial independence in the constitutional sense of meaning the protection of the magistrates so that they could administer justice and protect human rights ... [was] severely inhibited in the result'. ${ }^{6}$

4 Reports by L Kgalema \& P Gready, 'Transformation of the magistracy: Balancing independence and accountability in the new democratic order; Magistrates under Apartheid: A case study of professional ethics and the politicisation of justice'.

5 Refer to Laue (n 3 above), and the reports of Kgalema and Gready (n 4 above). 
Laue also states that the independence of judges goes back in history and tradition (a statement that cannot be accepted unconditionally in the light of the political influence that came to play in the appointment of judges), while the independence of the magistracy is a relatively recent innovation and a creation of statute. $\mathrm{He}$ does, however, also concede that the expression "judicial independence' means different things to different people. Some may say that it is merely a state of mind, whilst others consider it to be impartiality and fearlessness.

Section 165 of the Constitution ${ }^{7}$ provides that the judicial authority of the Republic is vested in the courts. The courts are subject only to the Constitution and the law which they must apply impartially and without fear, favour or prejudice. No person or organ of the state may interfere with the functioning of the courts; and the organs of state through legislative and other measures must assist and protect the courts to ensure the independence, impartiality, dignity, accessibility and effectiveness of the courts. In terms of section 166(d), Magistrate's Courts are part of the 'courts'.

Before 1994, Parliament was supreme. Not even the Supreme Court had, except in the limited sense of testing procedural correctness, the authority to strike any legislation down on the grounds that it infringed on the constitutional rights of the citizens. Magistrates were public servants who, apart from their judicial duties, were (and have until recently been) heavily burdened with administrative duties and also in later years, with certain onerous tasks in terms of the security legislation. The appointment, promotion, transfer, dismissal, disciplining and training of magistrates vested in the hands of the executive. Magistrate's Courts then, as now, were the courts with which the biggest part of the population came into close contact.

Magistrates administered law on a daily basis in courts that were not institutionally independent. The executive did not have a duty to assist and support the magistracy or to protect its independence, but controlled it. When the interim Constitution came into operation in 1994, those same magistrates continued to occupy the bench. It was required of them to take a new oath of office, in which they inter alia had to swear to uphold the Constitution. Suddenly the Constitution provided for their institutional independence and appointed the same executive who had until now been in control in a supportive and protective position.

The ability to apply the law independently, without fear, favour or prejudice, could not have been miraculously bestowed upon each 
serving magistrate overnight. Most magistrates had the desire and the ability to serve justice and to act without fear, favour or prejudice. If these subjective attributes are enough to make the magistracy independent, institutional independence becomes irrelevant.

The Constitution does not, however, refer to the independence of a magistrate, but clearly states that the court, ${ }^{8}$ of which the Magistrate's Courts form part, is independent, subject only to the Constitution and the law, which it must apply independently, without fear, favour or prejudice.

The essence of judicial independence was summarised by a Canadian judge, Judge Dikson: ${ }^{9}$

Historically the generally accepted core of the principle of judicial independence has been the complete liberty of individual judges to hear and decide cases that come before them. No outsider - be it government, pressure groups, individual or even other judge should interfere with the way in which a judge conducts his or her case and makes his or her decision.

The ability of the individual judge to make decisions in a concrete case, free from external interference, continues to be an important and necessary component of the principle.

Judge Le Dain distinguished three essential elements of judicial independence, namely: ${ }^{10}$

- security of tenure;

- a basic degree of financial security, free from the interference by the executive that could affect judicial independence; and

- institutional independence with respect to matters that relate directly to the exercise of the tribunal's judicial function. Although there is obviously a close relationship between independence and impartiality, they are nevertheless separate and distinct requirements. Impartiality refers to a state of mind or attitude of the tribunal in relation to certain issues and the parties in a certain case. The word 'impartial' connotes absence of bias, actual or perceived. The word 'independence' ... reflects or embodies the traditional constitutional value of judicial independence. As such it connotes not merely a state of mind or an attitude in the actual exercise of a judicial function, but a state of relationship to others, particularly to the executive branch of the government that rests on objective conditions and guarantees.

The test ... should be whether the tribunal may reasonably be perceived to be independent, and the test for independence should include that perception.

8 Sec 165.

$9 \quad$ Canada $v$ Beauregard 18630 DLR 48.

$10 \quad \mathrm{R} \vee$ Valente (1985) 2 SCR 673 (Canadian judgment). 
It is generally agreed that judicial independence involves both individual independence of the judge, as reflected in such matters as matters as security of tenure, and the institutional independence of the court or tribunal over which he or she presides, as reflected in its institutional or administrative relationships to the executive or legislative branches of the government ... The relationship between the two aspects is that an individual judge may enjoy the essential conditions of judicial independence, but that if the court or tribunal over which he or she presides is not independent of the other branches of government in what is essential for its function, he or she cannot be said to be independent.

These two judges differ substantially in their approach. Judge Dikson places the emphasis on the state of mind of the individual judge and the protection of subjective independence, while Judge Le Dain clearly sees the objective independence of the tribunal as the most important element of judicial independence. Even when referring to the individual judge, he sees the objective requirement of security of tenure and financial independence as a prerequisite.

In the case, the Judge found that: ${ }^{11}$

The status of a tribunal must guarantee not only its freedom from interference by the executive and legislative branches of government, but also by any other external force, such as business or corporate interests or pressure groups.

Here the emphasis once again seems to be on the subjective independence and freedom of the individual judge although the reference is to the tribunal.

The matter of the judicial independence of the magistracy has also been dealt with in tthe Constitutional Court and the High Court of South Africa.

In the matter De Lange $v$ Smuts $N O{ }^{12}$ the Constitutional Court, in deciding on the constitutionality of Section 66 of the Insolvency Act, ${ }^{13}$ dealt with the concept of the judicial independence of magistrates. The Honourable Judge Ackermann, in his judgment supported by the majority, dealt only with the separation of powers between the judiciary and the executive. 'This question, though simple, raises issues concerning the nature of the constitutional state and the separation of powers which must ultimately be solved within the context of the 1996 Constitution'. ${ }^{14}$ With reference to section $12(1)(b)$ of the Constitution, the judge concludes that a 'fair trial' requires, 15

199288 DLR (4th) 110 (Canadian judgment).

1998 (3) SA 785 (CC).

Act 26 of 1936.

De Lange (n 12 above) para 43.

De Lange (n 12 above) para 57. 
apart from anything else, a hearing presided over and conducted by a judicial officer in a court structure established by the 1996 Constitution and in which section 165 has vested the judicial authority of the Republic.

... Officers in the public service - in the executive branch of the state do not enjoy the judicial independence which is conditional to and indispensable for the discharge of the judicial function of a constitutional democratic state based on the rule of law. This independence, of which structural independence is an indispensable part, is expressly proclaimed and protected and promoted by sections 165(2), (3) and (6) of the Constitution.

The requirement set by the Constitutional Court for judicial independence is clearly that of institutional or structural independence.

It is interesting, though, to note the opinion of the dissenting judges on the issue of judicial independence. The Honourable Judge Didcott held that public officers that fall outside the magistracy (ie public servants) are unlikely to be less independent or impartial than those that are located within the magistracy (with special reference to the authority vested in the chairperson presiding over an inquiry in terms of the Insolvency Act to order the detention of a recalcitrant examinee detained in terms of section 66(3) of the Insolvency Act). The Judge pointed out that at the time of the judgment, the separation of the executive and the judiciary was not total and the magistracy, according to him, was a striking illustration of this. Magistrates had, besides their judicial work, a host of administrative tasks that fell within the exercise of the executive power, moving readily and frequently from the bench to the bureaucracy and back.

The Honourable Judge's opinion can be interpreted as meaning that institutional independence is not a prerequisite for judicial independence, and that a public servant can also act independently in exercising the discretion to order the detention of an examinee in terms of section 66. It can also mean that at the time of the judgement, he still regarded magistrates as actually not judicially independent.

In her judgment, Judge 0'Regan dealt with the principle of judicial independence in the following way: ${ }^{16}$

... but the independence and impartiality of the presiding officer is only the first aspect of judicial independence. It seems to me that the institution must also exhibit independence and impartiality in the judicial sense. 
This opinion seems to balance the requirements of an independent state of mind and institutional independence for judicial independence.

\section{Judge Sachs seems to hold a similar view: ${ }^{17}$}

By way of contrast, the authority to incarcerate for purposes of imposing penalties for past or continuing misconduct belongs to the judiciary, and to the judiciary alone. In my view, the doctrine of separation of powers prevents Parliament from entrusting such authority to persons who are not judicial officers performing court functions as contemplated by section 165(1).

Unlike other appointees, a magistrate exercising the power of committal to prison under section 66(3) of the Act will enjoy institutional independence and can be expected to apply the law impartially and without fear, favour or prejudice.

The protection of the judicial independence of the Magistrate's Court was the subject matter of two separate decisions in the Constitutional Court and the Transvaal Provincial Division of the High Court.

In the matter Van Rooyen and Others $v$ The State and Others (General Council of the Bar intervening), ${ }^{18}$ the Constitutional Court considered the questions of separation of powers, the independence of the judiciary and the comparison between the requirement of judicial independence of the High Court as compared to that of the Magistrate's Court. It is interesting to compare the way the Constitutional Court dealt with the judicial independence of the Magistrate's Court in this matter where they had to deal with the protection thereof, in comparison to the opinions on the matter in De Lange $v$ Smuts NO. ${ }^{19}$ In the last mentioned case, with the exception perhaps of Judge Didcott, the Constitutional Court did not differentiate between the independence of the higher courts and the Magistrate's Court. In Van Rooyen, the Constitutional Court held that 'the constitutional protection of the core values of judicial independence accorded to all courts by the South African Constitution meant that all courts were entitled to and had the basic protection that was required. ${ }^{20}$ Section 165 of the Constitution provided for this. The paternalistic view that the Constitutional Court took regarding the protection of the independence of the Magistrate's Courts is rather worrying. It was held that, in spite of the wording of section 165, the fact that all courts were considered by the Constitution to be independent, did not mean that that the lower courts had, or were entitled to have, their independence protected in

De Lange (n 12 above) 176.

20025 SA 244 (CC).

n 12 above.

Van Rooyen (n 18 above) para 22. 
the same way as the higher courts. In deciding whether a particular court lacked the institutional protection that it required to function independently and impartially, it was relevant to give regard to the core protection given to all courts by the Constitution, to the particular function that such a court performed and its place in the hierarchy. It does not mean that the lower courts had, or were entitled to have, their independence protected in the same way as the higher courts. Lower courts are entitled to the protection of the higher courts should any threat be made to their independence. Although the Constitutional Court in the same judgment found that judicial independence was a constitutional norm and principle that went beyond the Bill of Rights and was not subject to the limitation clause, the effect of the judgment was that the lower courts' right to protection of its independence was limited. Surely, an unlimited right to judicial independence should enjoy unlimited legal protection.

In Botha $\vee$ White, ${ }^{21}$ Judge Botha, in dealing with the question as to the nature of judicial independence, referred to the pronouncement of the late Chief Justice, Judge Ismail Mohammed: ${ }^{22}$

What judicial independence means in principle is simply the right and duty of judges to perform the function of judicial adjudication through the application of their own integrity, and the law, without any actual or perceived interference from or dependence on any other person or institution.

As shall be seen later, the late Judge President Mohammed placed a high premium on the subjective attributes of a judicial officer in establishing and maintaining his or her judicial independence.

The opinion expressed in Botha $v$ White was also quoted in the matter of Graham Noel Travers $v$ The National Director of Prosecution and Others ${ }^{23}$ in which, with reference to most of the authority quoted above, the learned Acting Judge stated: 24

In the final analysis I am of the view that undoubtedly magistrates enjoy the same level of judicial independence as judges do. Thus any decision on the part of the prosecuting authority regarding the finalisation of cases by magistrates amounts to an interference with the judicial independence of the magistrate.

It seems clear that there are divergent opinions even amongst judges from the High Court and the Constitutional Court as to whether judicial independence is a state of mind, or whether it can only exist in the context of institutional independence.

2004 (3) SA 184 (T).

n 21 above, para 37.

Judgment delivered by Ismail AJ in the Transvaal Provincial Division of the High Court of South Africa, Case 16611/04. 
It is also necessary to consider the opinions expressed by magistrates and other of the principal role players regarding the judicial independence of magistrates. Mr Laue states that it is important to remember that that judicial independence is neither self-executing nor static. ${ }^{25}$ The nature of judicial independence depends as much on the nature of the objective guarantees that are put in place (legislation and practical measures) as it does on the extent to which judicial independence is protected, assisted or undermined. With this must come the realisation that the expression means different things to different people. Some may say it is merely a state of mind while others label it as impartiality and fearlessness. While acknowledging the existence of differing viewpoints, Mr Laue is clearly an exponent of the view that institutional independence is a prerequisite for judicial independence.

On 26 June 1998, the late Judge Mohammed ${ }^{26}$ delivered a speech at the Second Annual General Meeting of the Judicial Officers Association of South Africa. ${ }^{27}$ His speech dealt with judicial independence and he remarked, inter alia:

Magistrates therefore have a very direct and crucial interest in securing their reputation for independence and integrity in order to protect themselves and the civilisation that they legitimately seek to mediate through the power of the law.

Judge Mohammed set out various institutional and infrastructural matters, which, according to him, directly or indirectly impacted on the capacity of magistrates to discharge their functions effectively, and enjoy public confidence. He then proceeded to discuss certain matters which, according to him, fell substantially in the domestic control of magistrates themselves, and was the basis of the capacity of an individual magistrate to strike a balance fairly coherently and ethically in the pursuit of justice. The Judge regarded these aspects to be arguably even more crucial to judicial independence than the institutional and infrastructural support basis. He set out the following aspects:

- experience

- scholarship

- dignity

- rationality

- forensic skill

- some measure of humility

- capacity for articulation

- discipline At that

27 n 23 above.

Published in (1998) 1 The Judicial Officer 47. 
- diligence

- intellectual integrity

- intolerance of injustice

- emotional maturity

- courage

- objectivity

- energy - both intellectual and physical

- rigour

- wisdom

- efficiency and a proper sense of relevance

- a healthy dose of scepticism about the correctness of a view of law which compels a manifestly unjust result

- the moral ability to distinguish right from wrong or two wrongs against each other.

Although the learned Judge regarded the institutional independence of the Magistrate's Court as important and worthy of the vigilance of magistrates, it is obvious that, in his opinion, it would be an empty 'independence' if individual magistrates lacked those subjective qualities that would make them fearless, fair and unbiased.

If institutional independence is in reality a prerequisite for judicial independence, Magistrate's Courts can only be truly independent if no interference or control by the executive or political interference exists, or if such interference is attempted, unconditional protection can be found in the higher courts.

Before 1993 and 1994, the executive would have had no perception of the judicial independence of magistrates, as it was effectively in control of the Magistrate's Court.

Some changes were brought about in the position of magistrates by the Magistrates Act and the 1994 and 1996 Constitutions as well as the fact that magistrates are now public office bearers. In spite of this, the influence of the executive and political powers has not been eliminated.

The Minister of Justice still plays an important role in the discipline of magistrates and still needs to be consulted by the Independent Remuneration Commission, before any recommendation regarding the remuneration of magistrates can be made to the President. The two houses of Parliament must approve any recommendations made to the President by the Independent Remuneration Commission, and this has in the past led to intolerable interference by politicians in the recommended remuneration of magistrates.

There are worrying indications that the executive still does not understand its constitutional role in terms of section 165 of the Constitution. On 14 December 2005, the Constitution of South Africa 
14th Amendment Bill was published for public comment under circumstances that led to a huge outcry from the legal fraternity. Although the Bill does not deal with the position of magistrates, it is a clear indication of the attitude of the executive towards the principle of judicial independence. The Bill was intended to be part of a package of measures designed to rationalise the judiciary in terms of section 6 of the Constitution. Although the outcry eventually led to the decision by the President to send the Bill back to the drawing board, the intention of the Bill still pops up every now and then. According to a recent press report, ${ }^{28}$ the provisions of the Bill have been resuscitated in a draft document by the ANC National Executive Council, drafted by a Department of Justice and Constitutional Development committee, chaired by the Minister of Justice and Constitutional Development, Ms Mabandla, and whose members included the Deputy Minister of Justice and Constitutional Development, Mr. De Lange, as well as a previous Minister of Justice, Advocate Penuell Maduna and various other politicians.

Professor Cathy Albertyn, Director of the Centre of Applied Legal Studies, came to the following conclusion regarding the proposed amendment: ${ }^{29}$

I have argued that several of the provisions of the Constitution 14th Amendment Bill demonstrate a worrying trend by the executive redrawing the lines of judicial independence and the separation of powers. In each case the line is shifted in favour of the executive. It also feeds into the perception that the government will step in to 'fix' things by extending the sphere of control or failing to relinquish it where appropriate.

The constitutional imperative to restructure the courts in line with the new Constitution needs to be carried out in a manner that engages the institutions of the state in a democratic dialogue that has the establishment of an independent, accountable and efficient judiciary as a goal. This entails breaking away from the current impasse and the executive instinct of constraining judicial institutional development. This instinct is clear from various comments made by the Deputy Minister of Justice and Constitutional Development on various occasions.

28 'ANC touches a sore judicial point' www.pretorianews.co.za/index.php?f Articleld=3748992 (accessed 28 March 2007).

29 C Albertyn 'Judicial independence and the Constitution 14th Amendment Bill' (2006) 4 South African Journal on Human Rights 126 at 142. 
The Honourable Judge-President of the Transvaal Division of the High Court, Judge Ngoepe, commented as follows on the relationship between the executive and the judiciary: ${ }^{30}$

Yet, occasions may arise when the executive is so much in control of the infrastructure in which judges operate, that the latter's' independence is imperilled. That is when judges are at the mercy of the executive. What is generally accepted is that judicial independence can be whittled away through a subtle process ... The final responsibility to protect the independence of the judiciary lies with the judges who should eventually decide whether any measures such as Acts of parliament undermine that independence and if they do, to strike them down.'

In order to protect the judicial independence of the magistracy, magistrates should vigilantly guard against any action on the part of the executive to infringe upon it, and act fearlessly to take steps to protect it. Magistrates, although they are bound by the Constitution and have a duty to interpret and even develop law according to the principles of the Constitution, cannot rule on the constitutionality of any Act of Parliament. They therefore have to look to the High Court and the Constitutional Court to protect their independence.

In my opinion it is clear that the executive still does not understand its constitutional role. In the case of magistrates the executive shows signs of suffering from separation anxiety, and in the words of Professor Albertyn, failing to relinquish control where it is appropriate. Even the Independent Remuneration Commission, whose report and recommendations regarding the remuneration of public office bearers, recently handed to the President, still fails to deal with the magistracy as an integral part of the judiciary, but applies different criteria to the remuneration of judges and magistrates. It seems that the remuneration of members of the executive still plays a role in the formulation of the recommendations regarding magistrates. On their website, ${ }^{31}$ the Independent Remuneration Commission also clearly distinguishes between the judiciary and the magistracy as separate groups of public office bearers. It sends the clear message that the constitutional position of the magistracy as part of the judiciary is not recognised even by the entity that is supposed to deal with the remuneration of magistrates.

The institutional independence of magistrates is a concept that has not been clearly established and developed. Magistrates, therefore, have to cherish and develop their subjective perception of independence by continuing to, subject to the control of the

30 'The relationship between judicial independence and judicial accountability: The package of draft laws on the judiciary' (A paper delivered on the occasion of the debate on the judiciary in a changing terrain. The debate was organised by the Institute for Democracy in South Africa (IDASA) in collaboration with Democratic Governance and Rights Unit (Unviersity of Cape Town): 11-12 October 2005). 
Constitution, act independently, without fear, favour or prejudice in order to eventually establish total institutional independence. This can only be achieved by maintaining at all times an independent state of mind.

Although I have not dealt with judicial accountability, it is obvious that judicial independence can never mean the freedom to act outside the bounds of the law and the Constitution. The Constitution sets clear boundaries for judicial independence and the judiciary should guard against individual judicial officers who overstep those boundaries. The executive should, however, not be allowed to, under the guise of judicial accountability, undermine the independence of the courts. 